\title{
Estimation of Supply and Demand Elasticities for Major Crops Produced in Pakistan
}

\section{Saima Rani ${ }^{*}$, David Vanzetti ${ }^{* *}$, Elizabeth Petersen ${ }^{* * *}$, and Muhammad Qasim***}

\begin{abstract}
This article studies the supply and demand of major Pakistani crops. We estimate supply elasticities using a Nerlovian partial adjustment process and demand elasticities using the Deaton and Muellbauer Almost Ideal Demand Systems (AIDS). We use secondary data from various Household Integrated Economic Surveys and Agricultural Statistics of Pakistan. Our estimated supply elasticities with respect to price lie between 0.1 and 0.5 for all crops. Pulses tend to have higher elasticities than traditional crops such as wheat and rice. Demand elasticities with respect to price tend to be inelastic, with the exception of poultry and fruit which appear to be luxury items. Pulses are income inelastic, implying that consumption may not rise significantly as per capita incomes and that the introduction of yield enhancing varieties will lead to lower prices.
\end{abstract}

Keywords: Supply, demand, elasticity, major crops, Pakistan.

JEL Classifications: Q11, Q19.

\section{Introduction}

In Pakistan wheat, sugarcane, cotton, and rice accounted for more than three-quarters of total crop output in 2015 (FAO, 2016). Wheat is the country's largest food crop in terms of production volume while cotton is both an important export commodity as well as key raw material to the local

\footnotetext{
* Scientific Officer, Social Sciences Research Institute, PARC National Agricultural Research Centre, Islamabad, Pakistan. Email: saimazahid6@gmail.com

** Senior Lecturer, Crawford School of Public Policy, Australian National University, Canberra. Email: david.vanzetti@uwa.edu.au

*** Principal Economist, Advanced Choice Economics P/L Adjunct Senior Lecturer, University of Western Australia. Email: Liz.Petersen@ tpg.com.au

**** Senior Scientific Officer, Social Sciences Research Institute, PARC National Agricultural Research Centre, Islamabad, Pakistan. Email: mqasim76@gmail.com
} 
textile industry. Rice is also an important cash crop and an important export while sugarcane is used in the production of white sugar and gur (jaggery) (Ministry of Finance, 2006). The cultivated area used to grow pulses is currently around 1.15 million hectares out of which major pulses (chickpea, lentils, mung bean and mash bean) used 1.09 million hectares. Chickpea and masoor (lentils) are the major rabi (winter) crops while mung and mash are the important kharif (summer) crops.

The production of pulses is lower than that of other competing crops and has been declining due to seed quality and poor crop management so that their prices have risen steadily for over the last decade (Figure 1 and Vanzetti et al., 2018). The observed increase in prices can be attributed to falling production and growth in population and incomes (Aazim, 2013; Khan, 2015; and Junejo, 2016).

The fluctuation in the area of major crops in Pakistan is given in figure 1.

Figure 1: Area under the different crop in Pakistan in 000,Ha

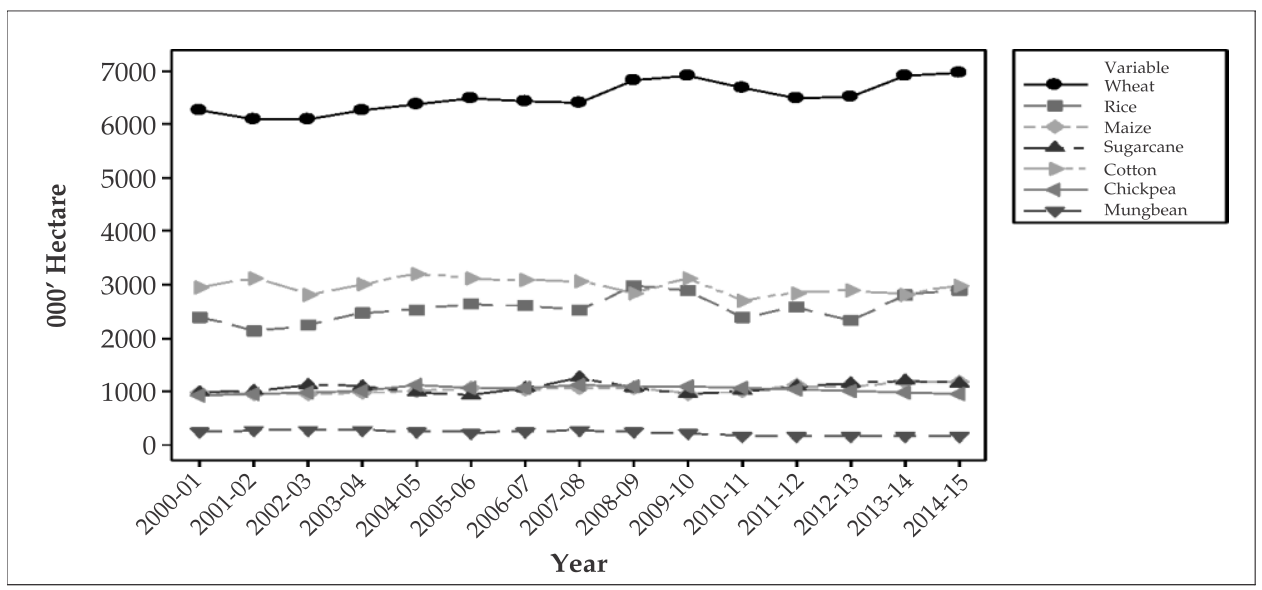

Source: Agricultural Statistics of Pakistan, 2015-16

Farmers prefer to grow crops whose yields and prices are relatively predictable and in Pakistan the prices of pulses tend to be unstable, especially compared to wheat and sugar where the government operates a price stabilization mechanism. Much of this price instability is due to fluctuations in total output (Rani et al., 2012) with bumper harvests leading to lower prices. 
Figure 2: Chickpea, Lentil and Wheat Prices in Pakistan

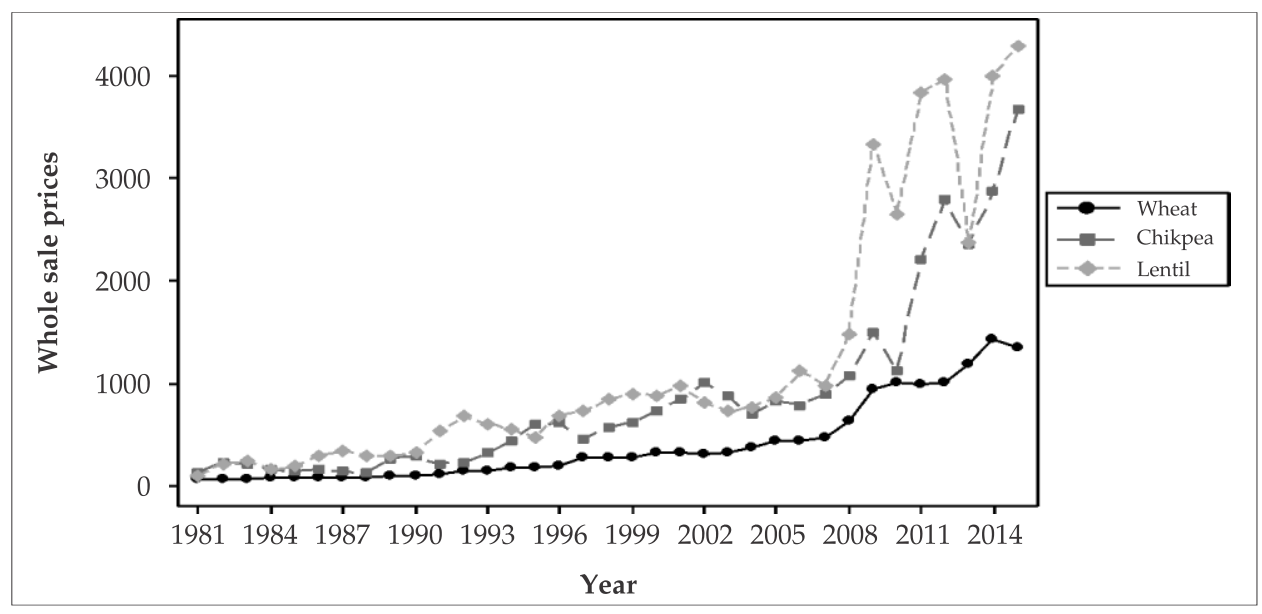

Source: Agricultural Statistics of Pakistan, Pakistan Office of Statistics

The significantly higher prices of important crops are what motivates research into understanding the consumer and producer responses to rising prices. Such an analysis is essential for policymakers attempting to design effective and pro-poor food policies. In this article, we estimate the elasticities of supply and demand for the major crops produced in Pakistan. This in turn can shed light on the potential impact of higher agricultural productivity, induced by research and development, since demand elasticities are important in determining the extent to which the benefits of a productivity enhancement will be shared between producers or consumers. If demand is inelastic, that is, not responsive to price changes, then an increase in productivity will benefit consumers. On the other hand, inelastic demand may be detrimental if the objective of policy makers is to help small producers.

\section{Empirical Methodology}

\section{A. Supply Response}

The production response equation of different crops is estimated at the national level data using Nerlove's partial adjustment model (Nerlove, 1958; Ali, 1998; Savadatti, 2006; and Rani, 2015; used a similar approach). The supply response function is specified as follows: 


$$
\begin{aligned}
Y_{i t}= & \beta_{0}+\beta_{1} P_{i t-1}+\beta_{2} P_{j t-1}+\beta_{3} Y_{i t-1}+\beta_{4} C_{t}+\beta_{5} I_{t}+\beta_{6} W_{r t}+ \\
& \beta_{7} W_{k t}+\beta_{8} F_{t}+\mu_{t}
\end{aligned}
$$

$Y_{i t}=$ Production of crop $i$ (kilotons) in year $t$;

$P_{i t-1}=$ Lagged relative farm harvest price $(\mathrm{FHP}) /$ Wholesale prices of concerned crop;

$P_{j t-1}=$ Lagged relative farm harvest price $(\mathrm{FHP}) /$ Wholesale prices of competing crop $j$;

$Y_{i t-1}=$ Lagged production of crop $i$;

$C_{t}=$ Cropping intensity (total cropped area divided by net sown area);

$I_{t}=$ Proportion of the irrigated area in the total cropped area;

$W_{r t}=$ Weather risk during the rabi season measured by the standard deviation from normal rainfall during growing months of crop $i$ (in $\mathrm{mms}$ ) measured over the three preceding years;

$W_{k t}=$ Weather risk during the kharif season measured by the standard deviation from normal rainfall normal during growing months of crop $i$ (in $\mathrm{mms}$ ) measured over the three preceding years;

$F_{t}=$ Fertilizer prices of urea and DAP of $50 \mathrm{~kg}$ in Rupees

$\mu_{t}=$ Error term.

Supply response variables are listed in Table 1 . The decision by farmers on how much of a particular crop to grow depends on the previous year prices of the crop, prices of competing crops and previous year's production. Cropping intensity measures the pressure on land and a negative coefficient for the impact of $\mathrm{C}_{t}$ indicates that an increase in the cropping intensity has a negative impact on the production of a crop. The irrigation intensity variable, $\mathrm{I}_{\mathrm{t}}$, measures the public and private investment in irrigation infrastructure over time. If the coefficient associated with this variable is positive, the crop has benefited from irrigation facilities.

\section{B. Demand Response}

A number of studies have used time series data to estimate demand functions (Schultz, 1938; Stone, 1953; Wold \& Jureen; 1953). The estimation of demand function in this study is based on Wold's market statistics approach to derive consumption, because of the lack of direct consumption 
data (which has also been used in other studies like Savadatti, 2006). We applied the Linear Approximate-Almost Ideal Demand System (LA-AIDS) methodology to estimate the demand function for all food items including pulses. This approach has also been used by other authors like Ali (1998), Ullah (2014) and Malik (2015). The model estimates both the own-price elasticity as well as cross price and income elasticities of demand. The model is specified as follows:

$$
\omega_{i}=\alpha++\beta_{i} \ln (x / p)+\mu_{i}
$$

$\omega_{i}=$ budget share of good $\mathrm{i}$

$P_{j}=$ price $\operatorname{good} j(\mathrm{j}=1,2, \ldots . \mathrm{n})$

$\mathrm{X}=$ total expenditure on all food items

$p_{i}=$ price of the $i_{\text {th }}$ commodity.

$\alpha, Y_{i j}$ and $\beta_{i}$ are the parameters in the equation. Demand response variables are listed in Table 2.

Table 1: Supply response variables

\begin{tabular}{|c|c|}
\hline Variable & Description \\
\hline$\overline{Y_{i t}}$ & Dependent variable (production of $i$ th crop in $\mathrm{kt}$ ) \\
\hline$P_{G(t-1)}$ & Lagged price of chickpea \\
\hline $\mathrm{P}_{\mathrm{M}(\mathrm{t}-1)}$ & Lagged farm price of mungbean \\
\hline $\mathrm{P}_{\mathrm{B}(\mathrm{t}-1)}$ & Lagged farm price of mashbean \\
\hline $\mathrm{PL}_{\mathrm{L}(\mathrm{t}-1)}$ & Lagged farm price of lentil \\
\hline $\operatorname{Pw}(t-1)$ & Lagged farm price of wheat \\
\hline $\mathrm{P}_{\mathrm{C}(\mathrm{t}-1)}$ & Lagged farm price of cotton \\
\hline $\mathrm{Pz}(\mathrm{t}-1)$ & Lagged farm price of maize \\
\hline $\mathrm{P}_{\mathrm{S}(\mathrm{t}-1)}$ & Lagged farm price of sugarcane \\
\hline $\operatorname{Pr}_{\mathrm{R}(\mathrm{t}-1)}$ & Lagged farm price of rice \\
\hline$Y_{i(t-1)}$ & Lagged production of ith crop in $\mathrm{kt}$ \\
\hline $\mathrm{C}_{\mathrm{t}}$ & Cropping intensity (total cropped area divided by net sown area); \\
\hline It & Proportion of the irrigated area in the total cropped area \\
\hline $\mathrm{F}_{\mathrm{t}}$ & Fertilizer prices of urea and DAP \\
\hline $\mathrm{W}_{\mathrm{rt}}$ & Weather risk during the Rabi season \\
\hline $\mathrm{W}_{\mathrm{kt}}$ & Weather risk during the Kharif season \\
\hline
\end{tabular}




\section{Table 2: Demand response variables}

\begin{tabular}{ll}
\hline Variable & Description \\
\hline$W_{\text {it }}$ & Dependent variable (Budget share of ith food) \\
$P_{C p}$ & Price of chickpea for consumer (Rs/KG) \\
$P_{\text {mung }}$ & Price of mung for consumer (Rs/KG) \\
$P_{\text {mash }}$ & Price of mash for consumer (Rs/KG) \\
Plentil $_{P_{\text {wheat }}}$ & Price of lentil for consumer (Rs/KG) \\
Price $_{P_{\text {meat }}}$ & Price of wheat for consumer (Rs/KG) \\
$P_{\text {milk }}$ & Price of rice for consumer (Rs/KG) \\
& Price of meat(mutton, beef and fresh fish)for consumer (Rs/KG) \\
$P_{\text {poultry }}$ & Price of milk(fresh and pasturized, packed, dried and condensed, butter, ghee, \\
$P_{\text {veg }}$ & yogurt, all converted into liquid milk equivalent)for consumer (Rs/KG) \\
Pfruit & Price of poultry(chicken) for consumer (Rs/KG) \\
& Price of vegetables(tomato, potato, onion, and other for consumer (Rs/KG) \\
& Price of fruit (citrus fruits, mango, apple, melon, graphs and dry fruits) for \\
\hline
\end{tabular}

\section{Data and Results}

We estimate the supply and demand elasticities using annual time series from 1981 to 2015 taken from secondary data sources. Supply side data is collected from the Agriculture Statistics of Pakistan (published initially by the Ministry of Food, Agriculture and Livestock and later by the Ministry of National Food Security and Research), the Economic Survey of Pakistan (published by the Ministry of Finance) and other statistical bulletins. To estimate demand, the use data from the nationally representative Household Income and Expenditure Survey (HIES) for the 15 years from 1984-85 to 2015-16. HIES collects detailed information on the quantity and value of consumption of various items by both rural and urban households across provinces. This information provides us with the budget share of the different food items to estimate the Linear Approximate Almost Ideal Demand System (LA-AIDS). The prices of different food items facing consumers were estimated by dividing expenditure with the respective consumption quantities. OLS was used to estimate the equation by assuming supply and demand are independent. Different variables were tested and finalized depending upon the goodness of fit and the Pearson Correlation test was used to quantify the degree and direction to which two variables are related. 
Supply response parameter estimates are provided in Table 3 and are generally consistent with expectations, with the exception of maize. Own price elasticities of the various crops are between 0.1 and 0.5 and the pulses tend to have higher elasticities than the traditional crops such as wheat and rice. The estimated elasticity for maize has the opposite sign. This probably reflects the correlation in crop prices. Farmers can substitute maize with sugar and rice and if the prices of maize and these other crops move together, farmers may switch out of maize if prices of other crops rise relatively further.

The cross-price elasticities show a less consistent pattern. A negative cross-elasticity indicates a substitute in production. This is to be expected, except in circumstances where crops are typically grown together. The cross-elasticity of chickpeas with respect to the price of lentils is positive, although insignificant. For our purposes, the most important cross-elasticity is between chickpeas and wheat, because we wish to analyze the impact of removing the wheat subsidy on pulse production. The cross-elasticity is quite high, -0.52, suggesting that chickpea production is quite responsive to the price of wheat. The cross-elasticity for lentils is -0.16 , less responsive but still significant. Mung is responsive to the price of maize (0.14) and mash to the price of rice (0.28). The results are similar to the study of Rani et al. (2015).

The traditional crops, wheat, sugar and maize, are not significantly affected by the prices of pulses. The exception is rice, which has a high cross-elasticity with mash (0.28). There is also substitution between rice and sugar, but rice production does not appear to be influenced by the price of maize. Wheat, which is supported by a government floor price, is not significantly affected by the prices of other crops. Lentils are found to be a substitute for mung but a complement to rice. The main conclusion to be drawn from the supply side estimates is that a fall in the price of wheat should provide a significant boost to the supply of chickpeas.

Chandrasekhara Rao (2004) examined Indian agricultural supply responses in Andhra Pradesh by using Nerlove's Partial Adjustment Model. The author found that non-price factors are more important determinants in aggregate agricultural supply than price related factors in the state of Andhra Pradesh. Mythili (2008) estimated supply responses for major crops during pre- and post-reform periods using a Nerlovian adjustment-cum- 
adaptive expectation model. Their estimation is based on dynamic panel data approach with data across states in India. They found no significant difference in supply elasticities between the pre- and post-reform periods for a majority of crops. They also found that farmers tend to respond to changes by adjusting non-acreage inputs rather than shifting the acreage. This includes better technology, use of better quality inputs and altering cultivation intensity.

As far as the cropping intensity is concerned, our results find that the production of pulses is mainly concentrated in areas with low cropping intensity. This suggests that their production is normally pushed to less fertile lands, which are marginal to main cereal and cash crop production. The negative effect of cropping intensity on the supply of pulses also reflects farmers' low preference for cultivating pulses as their main crop. 


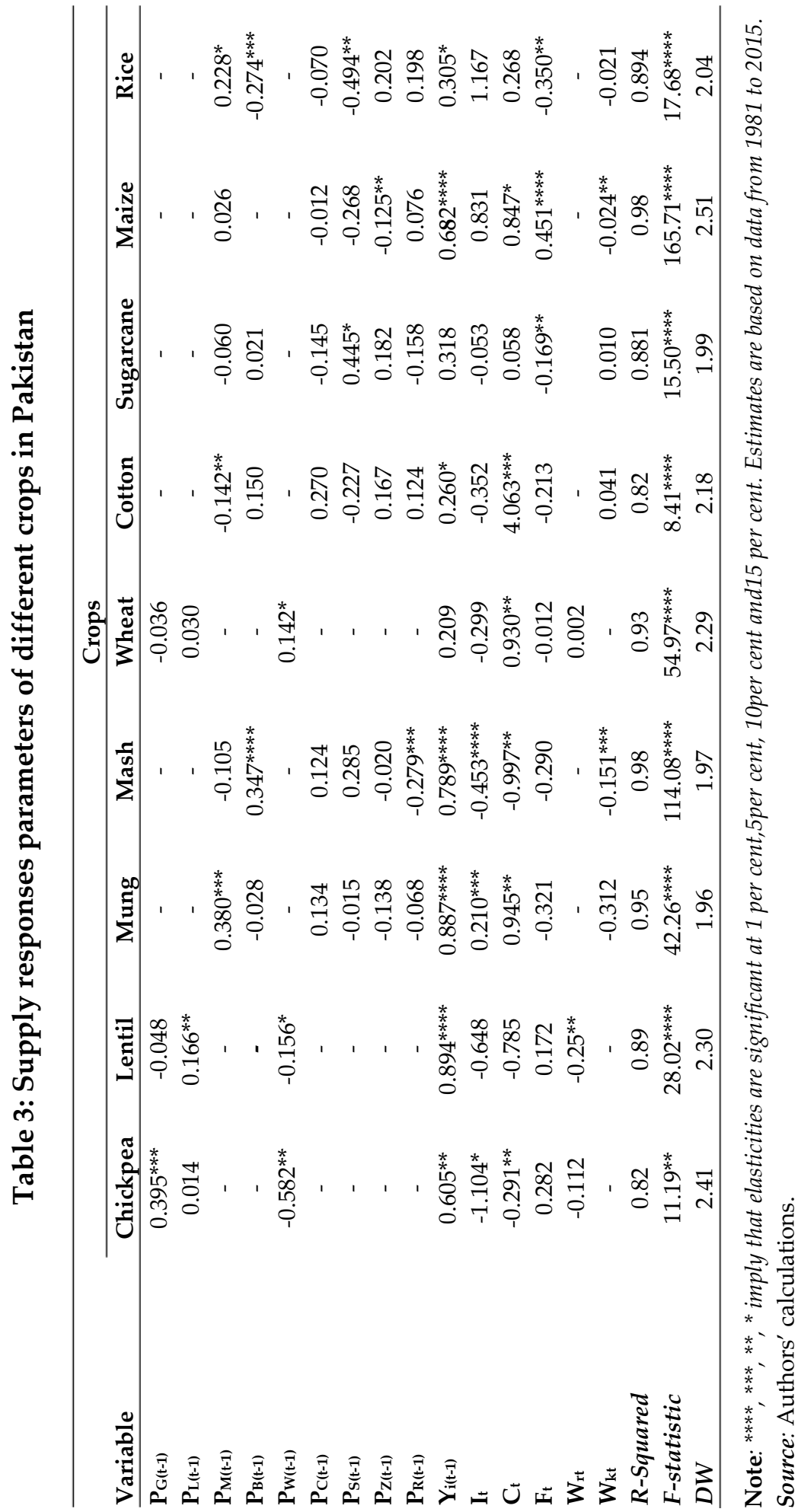


The own and cross prices elasticity estimates of demand for different food items in Pakistan are provided in Table 4. All the own-price elasticities have the expected signs and magnitudes. Nearly all are between 0 and -1 , signifying price inelasticity and essential nature of these goods, with the exception of poultry (-1.2) and fruit (-1.1). All of the own-price elasticities are significant except for vegetables. The estimated crosselasticities are less consistent; chickpeas are substitutes to mung and poultry but complements to wheat. Lentils are a substitute for mung and poultry but complementary to rice. Consumption of mung is affected by the price of chickpeas and poultry. Mash consumption responds to prices of chickpeas, mung and meat (beef and mutton). Wheat and rice are substitutes. Rice itself can be substituted by several foods, including wheat, chickpeas, fruit, milk and meat.

Moreover, this is confirmed by the low estimate of income elasticity, 0.20. As incomes grow, consumers prefer to switch from rice towards higher protein foods such as wheat, pulses, dairy products and meats. Pulses are somewhat substitutable with poultry, fruit and vegetables. This result is consistent with the findings of Farooq et al. (1999), Haq et al. (2011) and Malik (2015). These results may also be explained by the increased preference for dietary diversity. However, one would have expected a complementary relationship for cereal products with vegetable products in Pakistan, since cereal products are frequently consumed jointly with vegetables (especially potatoes). Our results may be driven by the impact of aggregation decisions of composite commodities.

Finally, we look at income elasticities (Table 5). As noted above, the higher protein foods are more income elastic, indicating consumers will switch into these as their incomes increase. Pulses are income inelastic, indicating that consumption may not increase significantly as per capita incomes increase. Based on income elasticities exceeding 1, meat, milk, fruit and poultry are luxury goods. 


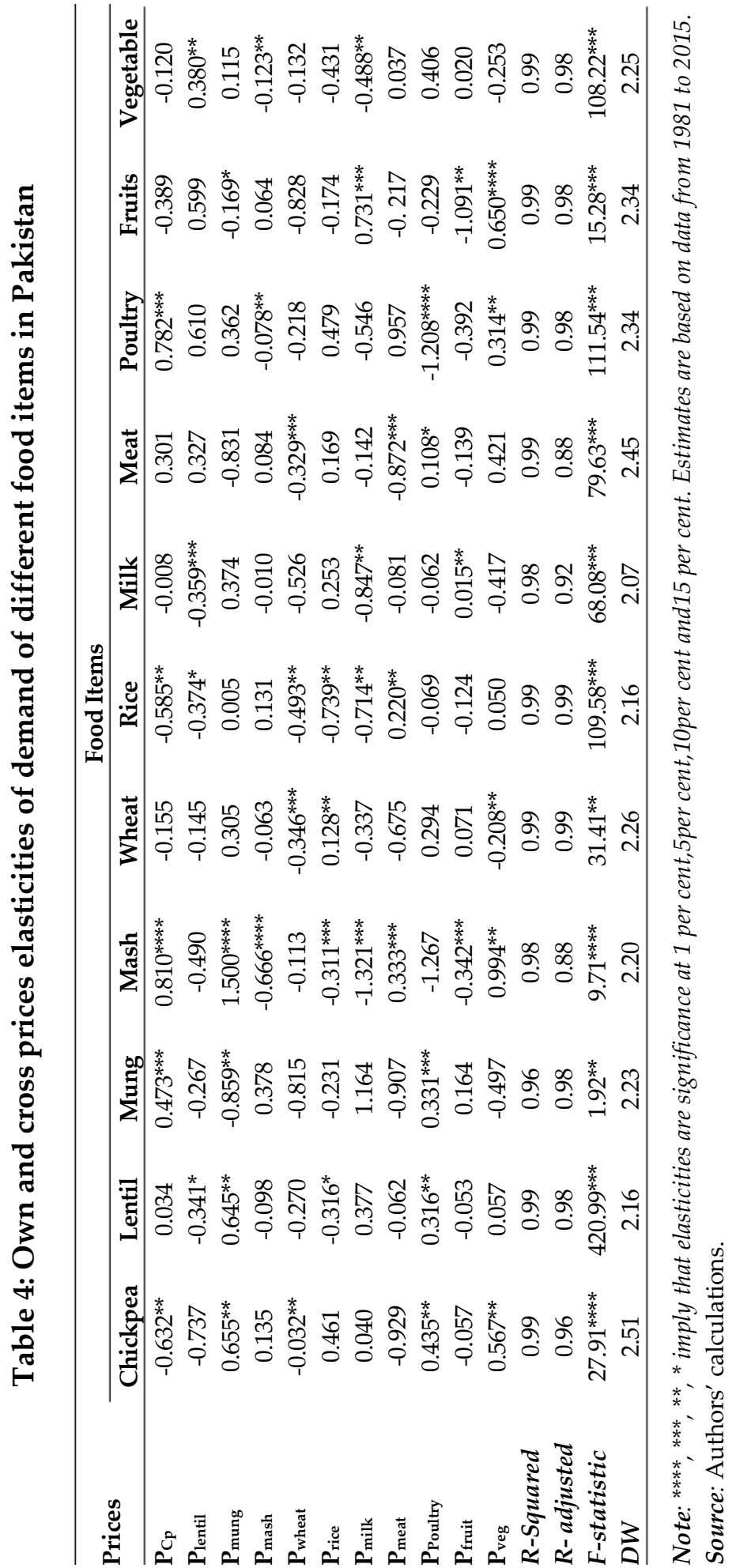


Table 5: Income elasticities of demand of different food items in Pakistan

\begin{tabular}{lc}
\hline Food items & Elasticity \\
\hline Chickpea & $0.730^{* * *}$ \\
Mung & $0.636^{* *}$ \\
Mash & $0.098^{* * *}$ \\
Lentil & $0.711^{* * *}$ \\
Wheat & $0.446^{* * *}$ \\
Rice & $0.191^{* *}$ \\
Meat & $1.502^{* * *}$ \\
Fruits & $1.646^{* * *}$ \\
Vegetable & $0.688^{* * * *}$ \\
Poultry & $1.667^{* * * *}$ \\
Milk & $1.036^{* *}$ \\
\hline
\end{tabular}

Note: ${ }^{* * *}, * * * * * *$ imply that elasticities are statistically significant at 1 percent, 5 percent and 10 percent.

Source: Authors' calculations.

\section{Summary and Conclusions}

There has been little attention given to food legumes by policy makers and researchers over the last few decades. Our results show that farm output prices and good weather conditions positively influence the area allocation decision made by Pakistani farmers. Farmers are price responsive and farm prices of pulses are much higher than the prices of competing crops like cereals, which should motivate pulse growers to increase the area devoted to the cultivation of pulses, though currently the production of pulses is mainly concentrated in areas of low cropping intensity. The estimated crosselasticities of supply indicate that a reduction in the subsidized price of wheat would lead to an increase in chickpea production. An output subsidy for pulses would increase production of all pulses.

On the demand side, all the own-price elasticities greater than -1 , with the exception of poultry (-1.2) and fruit (-1.1) and we find these estimated elasticities to be significant in all the cases except for vegetables. Pulses are income inelastic, indicating that consumption may not increase as incomes increase; furthermore, with inelastic demand for pulses, the introduction of yield enhancing varieties may lead to higher output and lower prices. Another interesting finding is that cereals tend to have the lowest expenditure elasticity of demand which reflect the fact that cereals are a staple of the Pakistani diet. Our findings can guide policy makers interested in projecting future food consumption and the policies required in the face of increasing incomes and a growing population. 


\section{References}

Ali, M., and Abedullah, M., (1998). Supply, demand, and policy environment for pulses in Pakistan. The Pakistan Development Review, 35-52.

Aziz, B., Khalil, M., Zahid, I., and Ijaz, H., (2011). Estimating food demand elasticities in Pakistan: An application of almost ideal demand system. Forman Journal of Economic Studies, 7, 2011, 1-24 .

Deaton, A., and Muellbauer, L., (1980a). An almost ideal demand system. American Economics Review, 70, 312-26.

Deaton, A., Muellbauer, L., (1980b). Economics and Consumer Behaviour. Cambridge: Cambridge, University Press, UK.

Food and Agriculture Organization of the United Nations (FAO), 2016. FAOSTAT. <http://faostat.fao.org/default>. Accessed April 14, 2016

Farooq, U., Young, T., \& Iqbal, M. (1999). An investigation into the farm households consumption patterns in Punjab, Pakistan. The Pakistan Development Review, 293-305.

Government of Pakistan, (2016). Government of Pakistan Agricultural statistics of Pakistan 2015-16, Ministry of Food Security and Research and Agricultural, Islamabad.

Government of Pakistan, (2017). Pakistan economic survey 2016-17, Finance division, Economic advisor's wing, Ministry of Finance Islamabad.

Haq, Z., Nazli, H., Meilke, K., Ishaq, M., Khattak, A., Hashmi, A. H., and Rehman, F. U. (2011). Food demand patterns in Pakistani Punjab. Sarhad Journal of Agriculture, 27(2).

Malik, S. J., (2003). Agricultural growth and rural poverty in Pakistan. Innovative Development Strategies (Pvt.) Ltd. Pakistan, Islamabad. Mimeo. 
Malik, S. J., Nazli, H., and Whitney, E., (2015). Food consumption patterns and implications for poverty reduction in Pakistan. The Pakistan Development Review, 54 (4), 651-669.

Ministry of Finance, Government of Pakistan, (2015). Economic survey of Pakistan, 2015-16. http://www.finance.gov.pk/survey/sur_chap_ 05-06/02-Agriculture.PDF. Accessed 17 January 2017.

Mohammed, A., (1983). Research and development in Pakistan agriculture. Islamabad: Pakistan Agriculture Research Council.

Mythili, G., (2008). Acreage and yield response for major crops in the preand post-reform periods in India: A dynamic panel data approach. PP Series 061. Mumbai: Indira Gandhi Institute of Development of Research.

Nerlove. M., (1958). Adaptive expectations and cobweb phenomena. The Quarterly Journal of Economics, 72 (2), 227-240, https://doi.org/ $10.2307 / 1880597$

Rani, S., Shah, H., Farooq, U., \& Rehman, B. (2014). Supply, demand, and policy environment for pulses in Pakistan. Pakistan J. Agric. Res., 27(2).

Savadatti, P. M., (2010). An econometric analysis of demand and supply response of pulses in India. Karnataka Journal of Agricultural Sciences, 20(3).

Schultz. H., (1938). The theory and measurement of demand. Chicago, Chicago University Press, Illinois, USA, 817.

Ullah, I., \& Jan, A. U., (2016). An estimation of food demand in Pakistan Using LA/AIDS. Sarhad Journal of Agriculture, 32(4).

Vanzetti, D., Petersen, E. H., and Rani, S., (2017). Economic review of the pulses sector and pulses-related policies in Pakistan. In Mid-Project Workshop of ACIAR Project ADP/2016/140 "How can policy reform remove constraints and increase productivity in Pakistan.

Wold, H., and Jureen, L., (1953). Demand analysis: A study in econometrics. John Wiley and Sons, New York. 